DOI 10.37882/2223-2982.2020.08-2.22

\title{
О СФЕРАХ ФУНКЦИОНИРОВАНИЯ АЛТАЙСКОГО ЯЗЫКА И ЕГО ДИАЛЕКТОВ: ПРОБЛЕМЫ И ПЕРСПЕКТИВЫ ${ }^{1}$
}

\section{ABOUT THE SPHERES OF FUNCTIONING OF THE ALTAI LANGUAGE AND ITS DIALECTS: PROBLEMS AND PROSPECTS}

\section{A. Chumakaev}

Summary: This article discusses how the Altai language and its dialects function. The identified difficulties faced by their realization in various areas of communication space are presented in correlation with their demographic power. Conclusions about the need to continue working to create favorable conditions for the wider use of the Altai language are supported by concrete facts.

Keywords: Altai language, dialect, language functioning, sociolinguistics, language situation, language policy.
A лтайский язык наряду с русским языком является государственным языком Республики Алтай (далее - РА) [1]. Указанный статус дает возможность для функционирования алтайского языка в различных сферах общественной жизни. Наиболее широко он используется алтайским населением республики в бытовом общении, затем в образовании и науке, культуре и СМИ. Также алтайский язык в более ограниченном объеме используется в ряде других сфер, о которых будет сказано позже.

Прежде чем говорить о функционировании алтайского языка и его диалектов необходимо пояснить, что основой алтайского литературного языка выступает диалект алтай-кижи, относящийся по традиционной классификации наряду с теленгитским и телеутским диалектами к южной группе алтайских диалектов. А северная группа включает тубаларский, кумандинский и челканский диалекты [2]. Тубалары, кумандинцы, челканцы, теленгиты и телеуты, являющиеся алтайскими субэтносами, имеют статус коренных малочисленных народов (далее - KMH) Российской Федерации (далее - РФ) [3, 4]. С одной стороны, языки общения этнических групп алтайцев считаются диалектами алтайского языка, с другой - отдельными языками, но в данной работе мы не затрагиваем вопрос об их языковом статусе, а опираемся на те формулировки, которые употребляются в анализируемых источниках.

В Материалах Всероссийской переписи населения
Чумакаев Алексей Эдуардович

НИИ алтаистики им. С.С. Суразакова (Горно-Алтайск) newchae@mail.ru

Аннотация: В данной статье рассматриваются сферы функционирования алтайского языка и его диалектов. Выявленные сложности, с которыми сталкивается их функционирование в тех или иных сферах коммуникативного пространства, представлены в корреляции с их демографической мощностью. Выводы о необходимости продолжения работы по созданию благоприятных условий, способствующих более широкому использованию алтайского языка, подкрепляются конкретными фактами.

Ключевые слова: алтайский язык, диалект, функционирование языка, социолингвистика, языковая ситуация, языковая политика.

2010 года [5] (далее - Перепись 2010) в разделе «Национальный состав населения» данные о теленгитах, тубаларах и челканцах выделены отдельно, но внутри сведений об алтайцах. Это объясняется тем, что указанные этнические группы проживают в основном в Республике Алтай. Информация по кумандинцам и телеутам дана в алфавитном порядке, отдельно от алтайцев. Кумандинцы преимущественно проживают в Республике Алтай, Алтайском крае и Кемеровской области, а телеуты - в Кемеровской области.

Количественные данные по РФ в целом об алтайцах и их этнических группах (KMH), указавших национальную принадлежность и владение языком соответствующей национальности, демонстрирует нижеприведенная таблица, отражающая результаты Переписи 2010.

Таблица 1.

Соотношение национальной принадлежности и владения языком

\begin{tabular}{|l|c|c|} 
Национальный состав & $\begin{array}{c}\text { Количество указав- } \\
\text { ших национальную } \\
\text { принадлежность }\end{array}$ & $\begin{array}{c}\text { Количество ука- } \\
\text { завших владение } \\
\text { языком }\end{array}$ \\
\hline Алтайцы & 74238 & 55720 \\
\hline Теленгиты & 3712 & нет данных \\
\hline Тубалары & 1965 & 229 \\
\hline Челканцы & 1181 & 310 \\
\hline Кумандинцы & 2892 & 738 \\
\hline Телеуты & 2643 & 975 \\
\hline
\end{tabular}

Работа подготовлена в рамках проекта РФФИ № 20-012-00426 «Динамика и перспективы языкового взаимодействия в республиках Южной Сибири» 
Соотношение национальной принадлежности и владения родным языком

\begin{tabular}{|c|c|c|c|c|c|c|c|}
\hline \multirow{2}{*}{$\begin{array}{c}\text { Национальный } \\
\text { состав } \\
\text { владение языками }\end{array}$} & \multirow{2}{*}{$\begin{array}{c}\text { Численность насе- } \\
\text { ления соответствую- } \\
\text { щей национальности } \\
\text { Владеющие языком }\end{array}$} & \multirow[b]{2}{*}{ Указавшие } & \multicolumn{5}{|c|}{ Владеющие языком } \\
\hline & & & алтайским & челканским & кумандиским & тубаларским & телеутским \\
\hline Алтайцы & 68814 & 68328 & 48583 & \multicolumn{4}{|c|}{ Нет сведений } \\
\hline Теленгиты & 3648 & 3635 & 3480 & - & - & - & - \\
\hline Тубалары & 1891 & 1888 & 303 & - & 1 & 201 & - \\
\hline Челканцы & 1113 & 1111 & 194 & 277 & 4 & 2 & - \\
\hline Кумандинцы & 1062 & 1061 & 64 & 2 & 212 & 3 & - \\
\hline Телеуты & 37 & 37 & 9 & - & - & - & 9 \\
\hline
\end{tabular}

Как показывает таблица, более или менее обнадеживающие данные по владению родным языком представлены у алтайцев, у коренных малочисленных народов ситуация неблагоприятная, о чем свидетельствуют и различные научные исследования $[6,7,8$ и др.]. Данных о владеющих теленгитским нет, т.к. те, кто причислил себя к теленгитам, в качестве родного языка, видимо, указали алтайский язык, что характерно для респондентов-теленгитов, которые не считают свой язык общения и алтайский язык разными языками.

Количественные данные по РА об алтайцах и КМН, указавших национальную принадлежность и владение теми или иными языками, представлены в следующей таблице, также составленной по Переписи 2010.

Таким образом, исходя из данных Переписи 2010 года о количестве владеющих теми или иными языками, можно предположить, что в бытовой сфере алтайский язык в РА использует 70,6 \% алтайцев и 52,25 \% представителей $\mathrm{KMH}$, их которых 44,8 \% составляют теленгиты, 7,45 \% остальные. Обращает на себя внимание низкий уровень владения тубаларами, челканцами и кумандинцами как алтайским, так и собственными диалектами, что свидетельствует об их ограниченном функционировании в речи представителей КМН. Следует отметить, что в среде КМН в основном происходят изменения социально-экономического характера, серьезных сдвигов в плане сохранения тубаларского, челканского и кумандинского не наблюдается, хотя отдельными энтузиастами работа в этом направлении ведется.

Несмотря на отсутствие в перечне языков теленгитского, считающегося по традиционной классификации диалектом алтайского языка, следует отметить, что теленгиты хорошо владеют алтайским литературным языком и своим диалектом в силу своей относительной многочисленности и компактности проживания.
Что касается телеутов, то в РА их численность незначительна, а алтайским и телеутским владеет только $24 \%$ процента из них. Поэтому можно сказать, что в РА телеутский практически утратился.

\section{Алтайский язык и его Аиалекты в образовании и науке}

Помимо бытовой сферы, алтайский язык широко используется в сфере образования и науки. В основном дети-алтайцы изучают алтайский язык в местах компактного проживания алтайцев или там, где имеются возможности для его изучения. В дошкольных и школьных организациях РА создаются условия для преподавания алтайского литературного языка. Издается разнообразная учебно-методическая литература, создаются электронные учебники и другая мультимедийная наглядность и т.д. На данный момент алтайский язык преподают в 89 (55\%) детских садах и в 127 (70\%) школах региона. В 2019-2020 учебном году 7495 (66,5 \%) обучающихся изучают алтайский язык по основной программе, 3765 чел. (33,5 \%) изучают по программе «Алтайский язык как государственный язык Республики Алтай» [9].

Следует отметить, что нет данных об общем количестве учащихся-алтайцев, включая учащихся из числа детей $\mathrm{KMH}$, а также нет сведений о том, какое количество указанных учащихся не изучает алтайский язык. Наличие этой информации позволило бы оценить реальную картину функционирования алтайского языка в сфере школьного образования. В настоящее время приходится констатировать факт, что некоторые дети-алтайцы по тем или иным причинам не изучают алтайский язык.

Также следует обратить внимание на то, что по программе «Алтайский язык как государственный язык Республики Алтай» занимаются учащиеся невладеющие или слабо владеющими алтайским языком, а это достаточно большое количество детей - 3765 чел. (33,5 \%), что вызывает определенную тревогу за будущее алтай- 
ского языка.

Учащиеся из числа КМН изучают алтайский литературный язык. Диалекты алтайского языка, или языки $\mathrm{KMH}$, при обучении алтайскому языку привлекаются как сравнительный материал. Как такового преподавания на языках КМН в республике нет [10].

Алтайский литературный язык преподается и изучается на школьном алтайском отделении Горно-Алтайского педагогического училища и на факультете алтаистики и тюркологии Горно-Алтайского государственного университета. Ведущим учреждением, проводящим актуальные исследования и издающим теоретически и практически значимые работы в области алтайского языка, является НИИ алтаистики им. С.С. Суразакова. Диалекты алтайского языка, или языки КМН, также находятся в поле научных интересов университета и института, а также ученых-лингвистов из Института филологии СО РАН (г. Новосибирск) и некоторых других учреждений.

Также следует отметить, что в рамках выполнения поручений Президента Российской Федерации [11] и Правительства Российской Федерации [12] в НИИ алтаистики им. С.С. Суразакова реализуется проект «Мониторинг языковой ситуации в Республике Алтай» [13, 14, $15]$.

\section{Алтайский язык и его диалекты в культуре}

Достаточно активно алтайский язык функционирует также в сфере культуры. Алтайский язык представлен в разнообразных музыкальных жанрах, в деятельности творческих и художественных коллективов, отдельных исполнителей. В репертуар Национального драматического театра им. П.В. Кучияка регулярно включаются постановки на алтайском языке.

Разнообразно использование алтайского языка при проведении тех или иных национальных алтайских праздников. Наиболее масштабным из них является Межрегиональный праздник Эл-Ойын (Народные игры), на котором можно услышать все языковое многообразие алтайского этноса. Это также можно сделать и во время проведения праздника Јылгайак (ДьылгайакПраздник весны). Северные алтайцы проводят народный праздник Јӱрӱк-Байрам (Дюрюк-Байрам - Праздник кедра), на котором можно услышать тубаларскую, кумандинскую, челканскую речь и песни.

Издательством «Алтын-Туу» выпускаются произведения алтайских писателей и другие материалы, в том числе и на языках КМH.

Практически нет созданных на алтайском материале мультипликационных и художественных фильмов, поэтому необходимо вести работу в этом направлении.

\section{Алтайский язык в СМИ}

Алтайский литературный язык представлен также в СМИ. С момента последнего нашего исследования функционирования алтайского языка в СМИ каких-то заметных изменений в перечне печатных изданий и в объеме публикуемых в них материалов на алтайском языке не произошло [16]. Новым для всех печатных СМИ, помимо обновления названий, рубрик и т.Д., является освоение ими сети интернет, т.е. создание сайтов и страниц в социальных сетях.

Единственной газетой, выходящей полностью на алтайском языке и имеющей приложения на алтайском и русском языках, является республиканская газета «Алтайдын Чолмоны», издающаяся тиражом 3510 экз. [17]. Также алтайский язык функционирует в газетах ряда районов со значительным количеством алтайского населения.

Отдельного телеканала и радио на алтайском языке нет. На алтайском языке филиалом ВГТРК ГТРК «Горный Алтай» - транслируются телепередачи («Сӱрлӱ кӱнле!», «Энирги солундар» и др.), а также радиопередачи. Следует отметить, что 6 из 9-ти отечественных мультфильмов советского периода, переведенных на алтайский язык и размещенных на сайте ГТРК «Горный Алтай» (http://elaltay.ru/) в разделе «Национальное вещание», заблокированы правообладателем для показа [18], поэтому, как уже было сказано выше, необходимо вести работу по созданию собственного материала на алтайском языке. Создано приложение сайта ГТРК «Горный Алтай» для Android.

Алтайский язык также осваивает интернет. Созданы различные сайты и страницы в социальных сетях на алтайском языке.

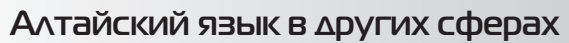

Помимо приведенных выше сфер, алтайский язык используется и в других сферах, в том числе указанных в Законе РА «О языках народов, проживающих на территории Республики Алтай» [1], но в меньшем объеме.

На алтайском языке публикуются тексты законов и других правовых актов, принятых законодательным и исполнительным органами РА. Он используется при проведении различных заседаний, собраний и т.д. Алтайский язык используется и в официальном делопроизводстве, судопроизводстве, а также в печатях, бланках, вывесках организаций, в указателях населенных пунктов и другой визуальной информации. 
Таким образом, в данной работе были рассмотрены сферы функционирования алтайского языка и его диалектов, которые, кроме диалекта алтай-кижи, являются языками общения КМН. Исследование по- казало, в какой мере алтайский язык и его диалекты функционируют в тех или иных сферах общественной жизни, какие имеются проблемы, которые необходимо решать для улучшения сложившейся ситуации.

\section{ЛИТЕРАТУРА}

1. Закон Республики Алтай от 3 марта 1993 года N 9-6 «0 языках народов, проживающих на территории Республики Алтай» [Электронный ресурс] http:// docs.cntd.ru/document/802008526) (дата обращения: 20.05 .2020 г.).

2. Баскаков Н.А. Очерк грамматики ойротского языка // Ойротско-русский словарь. - М., 1947. - С. 222.

3. Об утверждении перечня коренных малочисленных народов Севера, Сибири и Дальнего Востока Российской Федерации. Распоряжение Правительства РФ от 17 апреля 2006 г. N 536-р (в ред. Постановления Правительства РФ от 18.05.2010 N 352, 26 декабря 2011 г.). Версия 18 апреля 2014 [Электронный pecypc] http://www.raipon.info/activity/pravovaia-deiatelnost/federal-legislation/on-approval-of-the-list-of-indigenous-small-numbered-peoples-of-thenorth-siberia-and-far-east-of-th.php (дата обращения: 20.05 .2020 г.).

4. Чемчиева А.П. Алтайские субэтносы в поисках идентичности / Рос. акад. наук, Сиб. отд-ние, Ин-т археологии и этнографии. - Новосибирск: Изд-во ИАЭТ СО РАH, 2012. -254 .

5. Всероссийская перепись населения 2010 [Электронный ресурс] https://www.gks.ru/free_doc/new_site/perepis2010/croc/perepis_itogi1612.htm (дата обращения: 20.05 .2020 г.).

6. Сарбашева С.Б. Современная языковая ситуация у тубинцев // Социальные процессы в современной Западной Сибири: философские, политологические, культурологические аспекты. - Горно-Алтайск, 2000. - С. 166-173;

7. Озонова А.А., Николина Е.В., Кокошникова 0.Ю., Тазранова А.Р. Социолингвистическая ситуация у тубаларов и чалканцев // Языки коренных народов Сибири. Вып. 7. Часть 1. Экспедиционные материалы. - Новосибирск: изд-во НГУ, 2003. - С. 3-9;

8. Уртегешев Н.С. Социолого-лингвистическая ситуация у кумандинцев // Вестник Казахского национального университета им. аль-Фараби. - 2005. - N 5 (87). - С. 105-107; и др.

9. Этнокультурная составляющая содержания образования [Электронный ресурс] https://www.altai-republic.ru/society/education/ (дата обращения: 20.05.2020 г.).

10. Арефьев А.Л. Языки коренных малочисленных народов Севера, Сибири и Дальнего Востока в системе образования: история и современность - М.: Центр социального прогнозирования и маркетинга, 2014. - 488 с.

11. Перечень поручений по итогам совместного заседания Совета по межнациональным отношениям и Совета по русскому языку [Электронный ресурс] http://www.kremlin.ru/acts/assignments/orders/49877) (дата обращения: 21.05 .2020 г.).

12. 06 обеспечении выполнения поручений Президента России по итогам совместного заседания Совета по межнациональным отношениям и Совета по русскому языку [Электронный ресурс] http://government.ru/orders/selection/404/18910/ (дата обращения: 21.05 .2020 г.).

13. Чумакаев А.Э. 0 результатах реализации проекта «Мониторинг языковой ситуации в Республике Алтай» в 2016 г. // Актуальные вопросы алтайского языкознания: проблемы развития литературного языка, совершенствование современной орфографии: Материалы Всероссийской научно-практической конференции, посвященной 115-летию Т.М. Тощаковой. Редакционная коллегия: М.С. Дедина, А.Н. Майзина, А.Э. Чумакаев (отв. ред.). - Горно-Алтайск: Горно-Алтайская типография, 2017. - С. 152-158.

14. Чумакаев А.Э. 0 результатах реализации проекта «Мониторинг языковой ситуации в Республике Алтай» // История повседневности населения Западной Сибири и сопредельных регионов как форма цивилизационной идентичности Евразии [Электронный ресурс]: материалы Всероссийской с международным участием научной конференции (г. Бийск, 21-23 июня 2018 г.) / Отв. ред. А.В. Литягина. - Бийск: АГГПУ им. В.М. Шукшина, 2018. - С. $131-134$.

15. Майзина А.Н. 0 результатах мониторинга по изучению языковой ситуации в Республике Алтай [Электронный ресурc] http://bashkconference. ru/gallery/\%D0\%BC\%D0\%B0\%D0\%B9\%D0\%B7\%D0\%B8\%D0\%BD\%D0\%B0\%20\%D0\%B3\%D0\%BE\%D1\%80\%D0\%BD\%D1\%8B\%D0\%B9\%20 \%D0\%B0\%D0\%BB\%D1\%82\%D0\%B0\%D0\%B9.pdf (дата обращения: 19.05.2020 г.).

16. Чумакаев А.Э. Функционирование алтайского языка в печатных СМИ Республики Алтай: современное состояние // Актуальные вопросы алтайского языкознания: сборник научных статей. Отв. ред. А.Н. Майзина. - Горно-Алтайск: ОАО «Горно-Алтайская типография», 2008. - С. 100-107.

17. Периодические издания, телевидение и радио Республики Алтай [Электронный ресурс] https://www.altai-republic.ru/press-centre/periodicheskie-izdaniya/ (дата обращения: 20.05.2020 г.).

18. Алтай мультфильмдер [Электронный ресурс] http://elaltay.ru/index.php/altaj-berilteler/altaj-multfilder (дата обращения: 20.05 .2020 г.).

(с Чумакаев Алексей Эдуардович (newchae@mail.ru).

Журнал «Современная наука: актуальные проблемы теории и практики» 